\title{
Priorities for the conservation of mammals in the Peruvian Amazon
}

\author{
Richard E. Bodmer
}

Setting priorities for wildlife conservation in the Peruvian Amazon must deal with a variety of issues, including subsistence and commercial hunting, loss of habitat from deforestation, and the international trade in wildlife and wildlife products. However, what is the rank of these priorities for wildlife conservation in Peruvian Amazonia? One way to evaluate priorities for wildlife conservation is by determining how different human activities affect the number of animals removed from the populations. This yields a measure of the impact of these activities on animal populations and enables wildlife managers to rank priorities for wildlife conservation efforts.

In this paper the consequences of hunting, deforestation and international trade on mammalian populations in the Peruvian Amazon are examined. The impact on mammals from these different human activities will be ranked to obtain a better understanding of the priorities for wildlife conservation.

This paper will focus on the state of Loreto in north-eastern Peru, where numerous studies have been concerned with the conservation of mammals. Loreto covers an area of 379,450 $\mathrm{sq} \mathrm{km}$ and is situated entirely within western Amazonian forests. The forests of Loreto are some of the most biodiverse areas on earth (Gentry, 1988) and the integrity of this biodiversity will depend largely on the conservation of wildlife.

In common with many tropical forests, the rural areas of Loreto are inhabited by forestdwelling people, who will undoubtedly be the key to wildlife conservation efforts. In Loreto, non-tribal people dominate the rural areas; the 1981 census revealed that 280,000 non-tribal people lived in the rural sector of Loreto, comprising 85 per cent of the entire rural population. The remainder are indigenous people who have a population of 50,000 (Egoavil, 1992).

Non-tribal people are known in Loreto as ribereños and they obtain cash income and subsistence from fishing, agriculture, game hunting, small-scale timber extraction and collection of minor forest products (such as fruits, nuts and fibres) (Padoch, 1988). Ribereños, like Amazonian Indians, have a great knowledge of forest plants, agricultural techniques, and hunting and fishing methods. However, they differ from most Indian groups because of their intricate involvement in the market economy, both on regional and international levels (Lima, 1991).

In Loreto the majority of agriculture, hunting and fishing is carried out by ribereños. Communities of ribereños are organized around political units with rules for land use and extraction of natural resources being determined by the consensus of inhabitants within each community. These rules govern not only titled land officially owned by the communities, but also forest and fisheries resources of neighbouring areas.

This paper will focus on how the land use and extraction activities of ribereños affect mammalian populations, by examining hunting, deforestation and the international trade in wildlife.

\section{Methods}

The amount of hunting of wildlife populations in Loreto was analysed by estimating the 


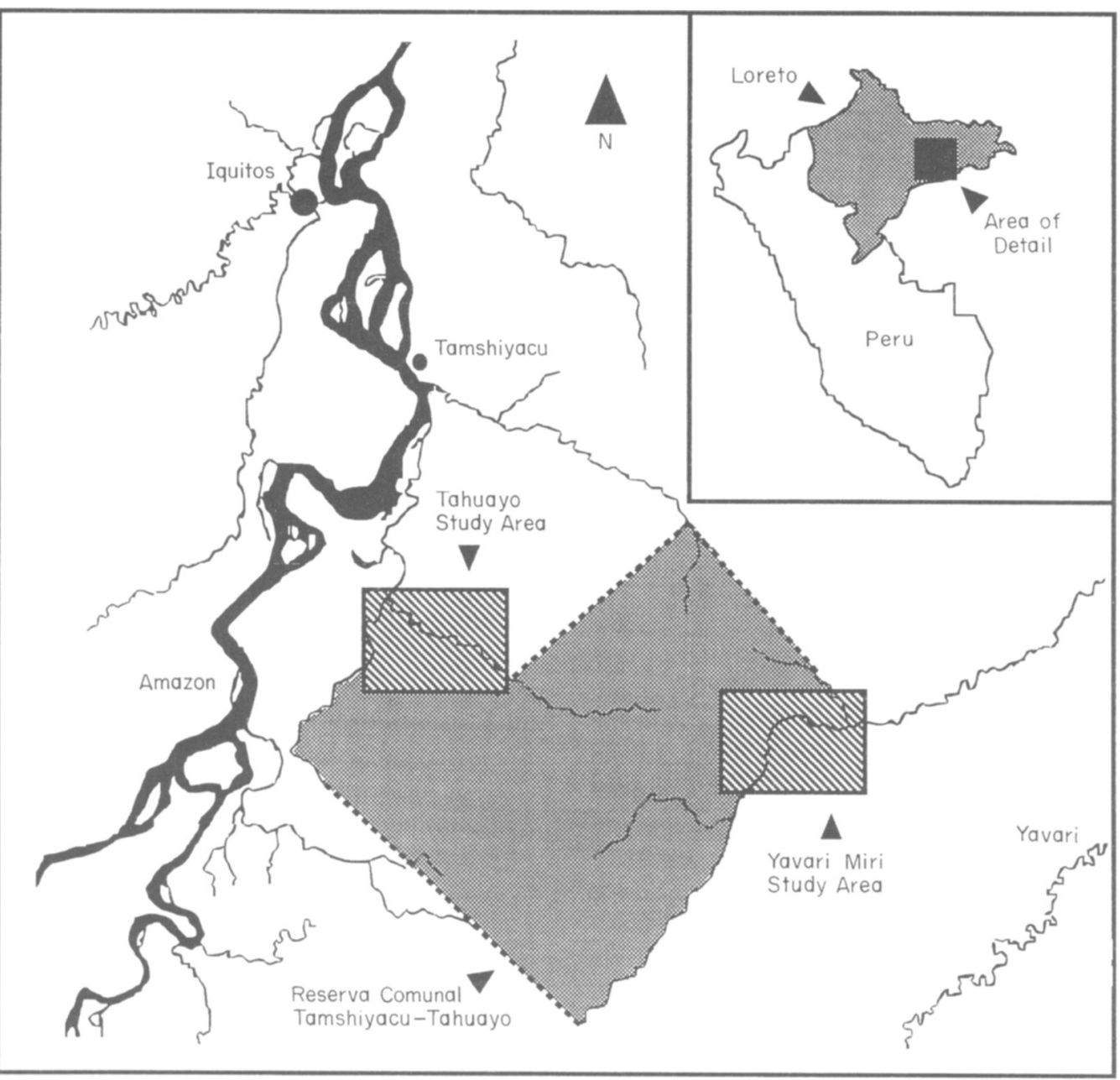

Figure 1. Map showing the state of Loreto, the persistently hunted Tahuayo study area, the infrequently hunted Yavari Miri study area and the Reserva Comunal Tamshiyacu-Tahuayo.

annual offtake of peccaries, deer, large rodents, tapirs and primates. These estimates used data on hunting by ribereños in two representative sites in the Reserva Comunal Tamshiyacu-Tahuayo. One site was next to the Yavari Miri River and was infrequently hunted, with an average of 1.1 mammals harvested/sq $\mathrm{km}$ per year, whereas the other, on the upper Tahuayo River, was persistently hunted, with an average of 2.7 mammals harvested/sq km per year (Bodmer, 1994) (Figure 1). Data from the infrequently hunted site were used to estimate the lower harvest offtakes, whereas data from the persistently hunted site were used to estimate the upper harvest offtakes.

The 203,260 sq km of 'production forests' of Loreto were used to extrapolate the Yavari Miri and Tahuayo harvest data to Loreto. Production forests are an official category of forest under Peruvian law and can be leased as timber concessions, and do not include private lands or forests under protection (COREPASA, 1986). Extrapolation of harvest data used the production forests because these are the main hunting ground of the ribereños.

The type of hunting was also analysed and classified as game hunted for subsistence and 
Table 1. Estimated annual harvests of mammals from Loreto. Lower harvest estimates use hunting data from an infrequently hunted area located in the Yavara Miri River and upper harvest estimates use data from a persistently hunted area in the upper Tahuayo River basin

\begin{tabular}{lrr}
\hline & \multicolumn{2}{l}{ Individuals per year } \\
\cline { 2 - 3 } Species & $\begin{array}{l}\text { Lower harvest } \\
\text { estimates }\end{array}$ & $\begin{array}{l}\text { Upper harvest } \\
\text { estimates }\end{array}$ \\
\hline Collared peccary* & 42,278 & 67,075 \\
White-lipped peccary & 35,773 & 67,482 \\
Brocket deer & - & 35,773 \\
Tapir & 15,447 & 17,886 \\
Paca & - & 70,734 \\
Agouti & - & 39,432 \\
Small-bodied primates & 3,252 & 8,536 \\
Large-bodied primates & 39,026 & 200,821 \\
Totals & 135,776 & 507,739 \\
\hline
\end{tabular}

* The lower harvest estimates for peccaries concur well with the number of peccary pelts exported from Loreto. The harvest estimates reported above include all age classes, which should be greater than the pelt exports. game hunted for sale in city markets. Data on the type of hunting came from studies carried out in the Reserva Comunal TamshiyacuTahuayo between October 1990 and October 1991. These studies recorded the number of game animals hunted and the use of the game species from a $500-\mathrm{sq}-\mathrm{km}$ area inhabited by 35 families who hunted regularly (Bodmer et al., 1994a).

The impact of deforestation on wildlife populations in Loreto was analysed by the amount of clear-cutting, using the assumption that clear-cutting converts wildlife habitat and removes all wildlife species. The effects of clear-cutting assume that the entirety of this habitat was suitable for wildlife prior to deforestation. These estimates do not consider edge effects because secondary growth around clear-cut areas is suitable wildlife habitat. Density estimates of species from the two representative sites were used to approximate the number of individuals in production forests prior to deforestation. Thus, the Yavari Miri study area, which had high densities of game mammals, was used to extrapolate the upper estimates of mammals removed due to deforestation and the Tahuayo study area, which had lower densities of game mammals, was used to extrapolate the lower estimates of mammals removed due to deforestation.

The impact of the international trade of animals and animal products on wildlife populations was analysed for the two legally ex- ported mammals and mammalian products from Loreto; primates for the biomedical trade and peccary skins for the European leather market. Data on the international trade of primates came from export figures of the Peruvian Primate Project. Data on the trade of peccary pelts came from records of the Ministry of Agriculture-Loreto.

\section{Results}

Ribereños take an estimated 135,776-507,739 peccaries, deer, tapir, large rodents and primates annually from the production forests of Loreto (Table 1). Ribereños hunt both for subsistence and to sell game meat in city markets. Between October 1990 and October 1991 hunters of the Reserva Comunal Tamshiyacu-Tahuayo sold 58 per cent of individual mammals captured to city markets and used the rest for subsistence. However, the amount of meat extracted for commercial sale $(19,128 \mathrm{~kg}$; 86 per cent) greatly exceeded the amount of meat consumed for subsistence $(2996 \mathrm{~kg} ; 14$ per cent), because they sold the larger species, such as peccaries, deer and tapir, and consumed the smaller species, such as primates.

Deforestation in the production forests of Loreto is calculated at $815 \mathrm{sq} \mathrm{km} /$ year (Dourojeanni, 1990). This is estimated to remove 85,491-146,046 peccaries, deer, tapir, large rodents, and primates annually (Table 2). 


\begin{tabular}{|c|c|c|}
\hline \multirow[b]{2}{*}{ Species } & \multicolumn{2}{|c|}{ Individuals per year } \\
\hline & $\begin{array}{l}\text { Lower removal } \\
\text { estimates }\end{array}$ & $\begin{array}{l}\text { Upper removal } \\
\text { estimates }\end{array}$ \\
\hline Collared peccary & 2,689 & 2,689 \\
\hline White-lipped peccary & 1,141 & 1,630 \\
\hline Brocket deer & 2,118 & 2,119 \\
\hline Tapir & 326 & 489 \\
\hline Paca & 2,852 & 3,912 \\
\hline Agouti & 2,934 & 3,097 \\
\hline Small-bodied primates & 49,717 & 83,945 \\
\hline Large-bodied primates & 23,716 & 48,165 \\
\hline Totals & 85,491 & 146,046 \\
\hline
\end{tabular}

Table 2. Estimated annual removal of mammals due to deforestation in Loreto. Lower estimates use density data from the upper Tahuayo study area and upper estimates use density data from the Yavari Miri study area.
A total of 8173 primates were captured for biomedical research during a 10-year period in Loreto, an average of 817 captured per annum (Tapia et al., 1990). The number of peccary pelts exported from Loreto averaged 57,000 per annum from 1980 to 1989 (Bodmer et al., 1993).

\section{Comparing hunting, deforestation and international trade}

Subsistence and commercial hunting by ribereños remove similar numbers of mammals. Hunting annually removes more individuals of game species than deforestation. Of the total number of mammalian game species removed annually by human activity in Loreto, 61-78 per cent are hunted, whereas 22-39 per cent are removed by deforestation.

However, deforestation and hunting affect species differently. The following four examples illustrate these differences.

1 Small-bodied primates are seldom hunted and hunting accounts only for 4-15 per cent of small-bodied primates removed from Loreto. Conversely, clear-cutting accounts for 85-96 per cent of small primates removed from Loreto. Indeed, most species with little or no value to people will be affected more by clear cutting than by hunting.

2 Peccaries, deer and large rodents are usually sustainably hunted in Loreto and current hunting pressure is probably not resulting in population declines in production forests (Bodmer et al., 1994a). Deforestation accounts for only around 5 per cent of peccaries, deer and large rodents removed from Loreto. However, deforestation is eliminating available habitat of these species and thus contributes to losses in their populations.

3 Populations of large-bodied primates are decreasing because hunting of these species is not sustainable in Loreto (Puertas and Bodmer, 1993). Hunting accounts for 45-89 per cent of the large-bodied primates removed from Loreto. Deforestation is also important and accounts for 11-55 per cent of the largebodied primates removed. This is an example where both deforestation and hunting contribute substantially to species' declines.

4 Hunting of lowland tapirs is causing population declines and local extinction and is not sustainable in Loreto (Bodmer et al., 1994b). Hunting accounts for $97-98$ per cent of the population decline of this species, whereas deforestation accounts for only 2-3 per cent.

Hunting and deforestation account for the majority of the wildlife removed from forests in Loreto, whereas the international trade in wildlife contributes only slightly to the overall harvest. For example, the offtake of primates by local hunters and the removal of primates due to deforestation greatly exceeds the removal of primates for the biomedical research trade. Between 98 and 99.6 per cent of primate harvests are due to hunting by ribereños and only 0.4-2.0 per cent are for international trade (Bodmer et al., 1994c).

Similarly, the trade in peccary pelts is not affecting the peccary harvests because the number of peccaries hunted in Loreto is deter- 
mined by the value of the meat rather than the value of the pelts. Hunters in Loreto earn around $\$$ US30 for the meat of one peccary in the city markets, whereas hunters receive only \$US1.5-2.0 for each hide. Indeed many rural hunters consider pelts as a minor by-product.

\section{Priorities}

Studies conducted in Loreto show that the priorities for wildlife conservation of mammals in the Peruvian Amazon should primarily be concerned with commercial and subsistence hunting by ribereños. Deforestation is of secondary concern and international trade of least concern.

Wildlife conservation in eastern Amazonia will be fruitless unless it focuses attention on the currently unmanaged game hunting. If game management is not improved, mammalian populations susceptible to over-hunting will decline and local extinctions will be unavoidable. Programmes that help ribereños to manage wildlife have been developed in Loreto and aim to replace unsustainable with sustainable hunting. Managing hunting also intends to maintain the value of forests for rural inhabitants, which in turn makes deforestation less desirable.

Rural wildlife management programmes were developed in Loreto because programmes developed in co-operation with ribereño communities are more effective at dealing with the problems than policing programmes. For example, in the Reserva Comunal Tamshiyacu-Tahuayo, communities are setting up a management programme that allows hunters to cull a greater proportion of males of species that are not currently overhunted, and cease hunting over-exploited mammals. This management programme integrates economies of local people by maintaining their needs for marketable products and simultaneously reduces hunting of threatened species.

Conservation efforts in Loreto also attempt to counteract deforestation. This has led to programmes that curb clear-cutting rates through sustainable agriculture. Agroforestry programmes are designed to reduce rates of deforestation by allowing ribereños to keep converted land in production longer and thus diminish the need to clear-cut forests (Dourojeanni, 1990).

In Loreto, both the trade in primates for biomedical research and the trade in peccary pelts are monitored in accordance with CITES (Convention on International Trade in Endangered Species of Wild Fauna and Flora) regulations. These stipulate that management authorities not only monitor the trade, but also monitor the effect of the trade on species populations. Studies conducted by the Peruvian Primate Project have clearly shown that the primate trade for biomedical research has little or no long-term effects on the primate populations (Proyecto Peruano de Primatología, 1990). Similarly, studies of the peccary pelt trade have shown that pelt exports are not influencing peccary harvests (Bodmer et al., 1993).

Wildlife conservation efforts currently under way in Loreto are dealing with all the priorities outlined above. The continuation of these conservation efforts should focus appropriately on the priorities if conservation of mammals in the Peruvian Amazon is to be successful. In the past, most of the efforts devoted to conservation in Loreto focused on deforestation and the international wildlife trade, largely ignoring hunting by ribereños, which was the major cause of declines of wildlife populations. More recently there is an increased awareness of the urgency of finding solutions for rural hunters. These solutions should convert unmanaged hunting to managed hunting and incorporate information both on the biology of mammalian populations and the socioeconomic realities of ribereños.

\section{Acknowledgments}

I thank T. Fang, J. Penn, P. Puertas, L. Moya and I. Vilchez for their kind assistance. Logistical and financial support was provided by the Chicago Zoological Society, Proyecto Peruano de Primatología 'Manuel Moro Sommo', Dirección Regional de Recursos Naturales y de Medio Ambiente - Loreto, Facultad de Ciencias Biológicas 
of the Universidad Nacional de la Amazonía Peruana, and the Amazon Conservation Fund.

\section{References}

Bodmer, R.E. 1994. Susceptibility of mammals to over hunting in Amazonia. Proceedings of the International Wildlife Management Congress (in press).

Bodmer, R.E., Sowls, L.K. and Taber, A. 1993. Economic importance and human utilisation of tayassuids. In Pigs, Peccaries and Hippos: Status Survey and Conservation Action Plan (ed. W. Oliver), pp. 29-36. IUCN, Chicago.

Bodmer, R.E., Fang, T.G., Moya, I., L. and Gill, R. 1994a. Managing wildlife to conserve Amazonian forests: population biology and economic considerations of game hunting. Biological Conservation, 67, 29-35.

Bodmer, R.E., Puertas, P., Moya, I., L. and Fang, T.G. 1994b. Estado de las poblaciones del tapir en la Amazonia Peruana: En el camino de la extincion. Boletin de Lima (in press).

Bodmer, R.E., Puertas P. and Fang, T.G. 1994c. The urgency of finding new directions for primate conservation in western Amazonia. Neotropical Primates, 2, 1-3.

COREPASA. 1986. Plan Maestro de la Reserva Nacional Pacaya-Samiria. Editorial e Imprenta DESA, Loreto, Peru.

Dourojeanni, M.J. 1990. Amazonia ?Que Hacer? CETA, Iquitos, Peru.
Egoavil, E.O. 1992. Perfil Demografico de la Region Loreto. Instituto de Investigaciones de la Amazonia Peruana, Iquitos, Peru.

Gentry, A.H. 1988. Tree species richness of upper Amazonian forests. Proc. Nat. Acad. Sci. 85, 156-159.

Lima, D. 1991. Kin saints and the forest: the study of Amazonian Caboclos in the middle Solimões Region. $\mathrm{PhD}$ thesis, University of Cambridge.

Padoch, C. 1988. People of the floodplain and forest. In People of the Tropical Forest (eds J. S. Denslow and C. Padoch), pp. 127-141. University of California Press, Berkeley.

Proyecto Peruano de Primatología. 1990. La Primatología en el Peru: Investigaciones Primatológicas. Propaceb, Lima, Peru.

Puertas, P. and Bodmer, R.E. 1993. Conservation of a high diversity primate assemblage. Biodiversity and Conservation, 2, 586-593.

Tapia, J., Encarnación, F., Aquino, R., Moya, L. and Soini, P. 1990. Censos poblacionales y saca periodicas de primates en la Amazonia Peruana (1976-1985). In La Primatologia en el Peru: Investigaciones Primatológicas (ed. Proyecto Peruano de Primatología), pp. 325-341. Propaceb, Lima, Peru.

Richard E. Bodmer, Tropical Conservation and Development Program, Center for Latin American Studies, University of Florida, 319 Grinter Hall, Gainesville, FL 32611, USA. 